\title{
PHYSICOCHEMICAL CHANGES OF DWARF BANANA (Musa acuminata) DURING VACUUM PACKAGING STORAGE
}

\author{
David Septian Sumanto Marpaung ${ }^{1,3 凶}$, Dwi Cahyani ${ }^{1,3}$, Ni Wayan Arya Utari ${ }^{1}$, Anggia \\ Indriyani $^{2}$, Resa Apriliani ${ }^{1}$ \\ ${ }^{1}$ Department of Biosystems Engineering, Institut Teknologi Sumatera \\ ${ }^{2}$ Department of Agriculture Engineering, Universitas Lampung \\ ${ }^{3}$ Research and Innovation Center for Conservation and Renewable Energy, Institut Teknologi Sumatera \\ ${ }^{\otimes}$ Komunikasi Penulis, email: david.marpaung@tbs.itera.ac.id \\ DOI:http://dx.doi.org/10.23960/jtep-lv10i2.193-199
}

Naskah ini diterima pada 6 Maret 2021; revisi pada 21 April 2021;

disetujui untuk dipublikasikan pada 3 Mei 2021

\begin{abstract}
Banana is tropical fruit contain health nutrition and fiber. Dwarf banana is one of type banana that well growth in Indonesia, particularly in Lampung Province. However, its economic value become exported commodities is limited by its short shelf life. In this study, the physicochemical changes were observed under vacuum packaging storage, in order to know the potency of vacuum packaging to prolong the shelf life of dwarfbanana. The results showed that the vacuum packaging could reduce weight loss compare to other treatments. The maintenance of green color by vacuum packaging was also showed positive result. Furthermore, the dwarfbanana under vacuum packaging storage was also showed lowest TSS, in other words, the dwarf maturity could be delayed. These results suggested the vacuum packaging could be used as potential packaging for dwarf banana
\end{abstract}

\section{Keywords: dwarfbanana, vacuum packaging, postharvest, physicochemical properties}

\section{INTRODUCTION}

Banana is a tropical crop that grown well in Indonesia, particularly in Lampung Province. Its nutrition and bio-function make these fruits important around the world (Jideani, 2019). In 2019, Lampung contributed 16\% (1,209,545 ton) of total banana production in Indonesia (BPS, 2019), indicated by the improvement of quantity and quality of banana production in Lampung will affect the banana consumption nationally.

Dwarf banana is one of the banana varieties in Indonesia, locally known as "pisang muli". Dwarf banana is growing well in Indonesia, particularly in Lampung and Sulawesi. The demand for dwarf bananas tends to increase, due to their taste and nutrition which healthy. However, dwarf bananas still unable contributed to be exported commodities from Indonesia (Tambunan and Faradilla, 2019), due to their bad postharvest handling. As its perishable characteristics become the challenges, proper postharvest handling must be applied to tackle the short shelflife issue.
Several postharvest handling has been conducted to extend the shelf life of a dwarf banana. A nano-emulsion was used to minimize the post-harvest losses and to extend the shelf life of a dwarf banana. The results clearly showed that the shelf life of dwarf banana fruit was extended up to six days in ambient conditions and nine days in cold storage conditions (Venkatachalam et al., 2018). Another study to extend the shelf life of dwarf banana was using edible coating, xanthan gum (Tambunan and Faradilla, 2019). The dwarf banana is not only being extended its shelf life up to ten days by using xanthan gum but also reduced its postharvest losses. Also, another postharvest treatment on using $\mathrm{KMnO}_{4}$ to prolong the shelf life of dwarf bananas was already conducted earlier (Dahli et al., 2014). However, there is no much information about packaging methods that are used to prolong the dwarf banana shelf lifetime.

To meet the customer in the correct state, fresh bananas must be correctly sold, taking into account the application of the most acceptable temperature and humidity, as well as 
appropriate packaging and handling procedures. Good packaging will not also determine the quality of the product, but also will gain consumer preferences (Marpaung et al., 2019). Proper handling during harvesting can reduce mechanical loss and reduce eventual waste due to microorganism contamination (Marpaung et al., 2020). Traditional packaging methods for bananas are using dried banana leaves and teff straw as the materials (Hailu et al., 2014). However, the efficacy of these packaging materials was very low. Another packaging method, such as vacuum packaging has been known to extend the shelf life of many agriculture products (Gorris and Peppenlenbos, 1992). Therefore, in this study, the vacuum packaging and other packaging using PE plastic was investigated the physicochemical changes of dwarf bananas. The physicochemical changes, such as color, weight, and total soluble solids related to the shelf life of a dwarf banana. This study aimed to investigate the physicochemical changes of dwarf bananas.

\section{MATERIALS AND METHODS}

\subsection{Sample Collection}

The dwarf banana (Musa acuminata) was obtained from a local market (Bandar Lampung, Lampung, Indonesia). The equal maturity level of dwarf bananas was then adjusted by their color appearances. The dwarf banana fruits was selected and divided randomly into twelve groups ( 3 fruits in each group), and each group was used for each of the packaging conditions.

\subsection{Packaging Conditions}

The dwarf banana was packaged under three conditions. The material that used to package was PE plastic. These conditions were: (1) vacuum packaging, (2) sealed plastic and (3) perforated seal. The sample was stored in the room temperature condition in the laboratory of Biosystems Engineering, Institut Teknologi Sumatera. The temperature conditions were range $25.6-25.7^{\circ} \mathrm{C}$ and $\mathrm{RH}$ range $82-83 \%$.

\subsection{Total Soluble Solids and Color Analysis}

The dwarf banana peel color was measured with an android application (colorimeter), the detail action of color capture followed Ravindranath et al., (2018), on three different side points (Fig 1). The CIE L*, a*, and b* system was used to quantify color values. In order to reduce the different light intensity, the flash from android was activated. The dark spots were avoided while investigating the banana fruit. Results were obtained, as L* (lightness from 0 (black) to 100 (white)), a* (redness/greenness from $+a^{*}$ is redness to "a* is greenness), and b* (yellowness/blueness from $+b^{*}$ is yellowness to " $b$ * is blueness). The color appearance was then analyses in colorimeter.org. While, the total soluble solid contents (TSS) of dwarf banana was measured using a refractometer (Atago Co. Ltd., Minato-ku, Japan) at its environmental temperature.

\subsection{Weight Loss}

The weight loss was quantified by using scientific balance. The initial and final weight of each sample treatment was measured followed the equation below:

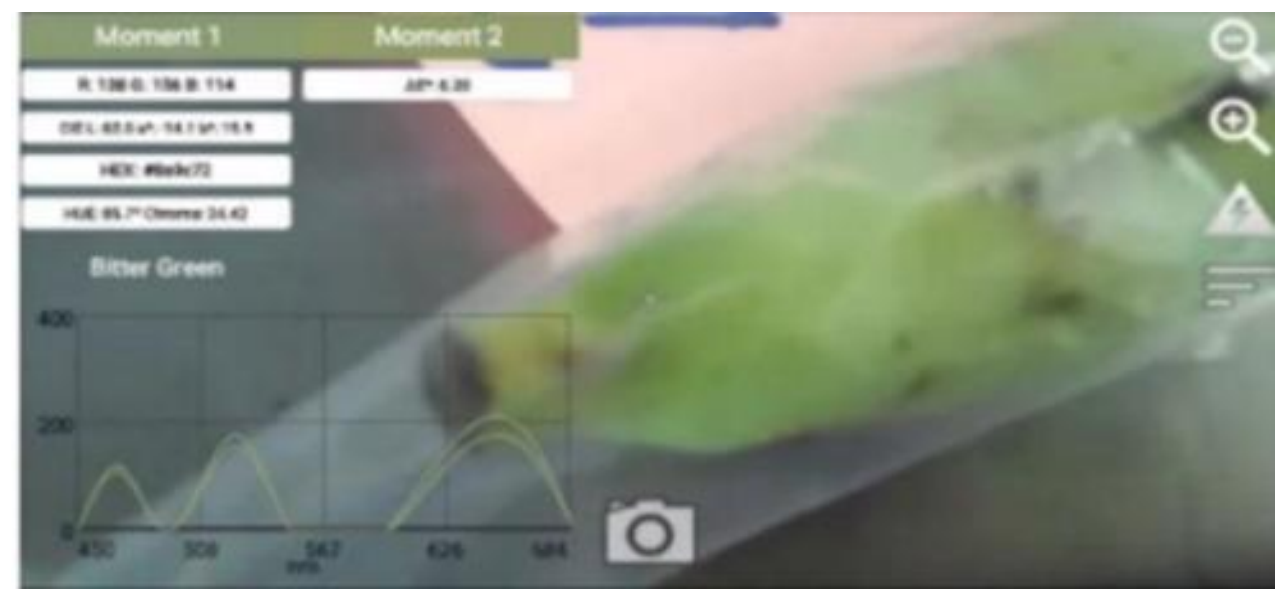

Figure 1. Color Analysis Using Android Apps 
Weight Loss $(\%)=\left(\frac{\text { Initial Weight. }}{\text { Finul Weight }} *\right.$ Initial Weight $) \times 100 \%$

\subsection{Data Analysis}

The TSS of dwarf banana at day 6 were analyzed by analysis of variance (ANOVA) procedure with TSS as response variable and treatment as factor, in order to know the impact of packaging treatment to TSS of dwarf banana. The comparisons of the TSS results means were done using Duncan's Multiple Range Test (DMRT). Three replications were used in this study for each treatment of packaging. The mean and standard deviation was used to know the variation of data.

\section{RESULTS AND DISCUSSION}

\subsection{The Weight Loss}

In order to know the weight loss of dwarf banana, the initial and final weight of sample was quantified. The weight changes of dwarf banana are showed in Fig 2. The lowest changes of dwarf banana weight were found in vacuum sealer treatment, with $2.49 \%$ (Fig 3) weight loss. Another packaging treatment was resulted $4.12 \%$ in sealed plastic packaging and $3.72 \%$ in perforated seal packaging. Similar to previous results, the banana (Musa paradisiaca) in vacuum packaged was able to keep the weight loss up to 23 days with $7 \%$ weight loss, compare to its control treatment which had $7.5 \%$ weight loss within 4 days (Sunisha et al., 2019). Another study in packaging materials impact to banana shelf life extension showed that polyethylene bag was the best materials to keep the weight loss of banana during packaging storage up to 16 days compare to other materials, including carton box, banana leaf and teff straw (Tsegaye, 2020).

The weight loss during storage could be increased, caused by the loss of moisture through stomata cells of agriculture product. The transpiration of fruit during storage is partially relying on temperature and humidity (Baldwin, 1994). In further explanation of moisture loss in fresh fruits and vegetables, the loss occurred because of differences in the water vapour pressure in their storage environment which allow to vapour diffusion (Yaman and Bayoindirli, 2002). Compare to other packaging methods, the vacuum packaging had very low moisture permeability that impact to the low moisture loss activity. In the certain country, the maximum levels of weight loss of vegetables will not allowed more than 10\% (Thompson et al., 2008). In this study, the vacuum packaging was only reached below $10 \%$ weight loss within 6 days storage. It is indicated that vacuum sealer packaging is potentially worked for dwarf banana packaging.

\subsection{Color Changes}

Color is an important indicator of maturity in many fruits. In order to know the maturity level from physical appearances, the peel color changes of dwarf banana were observed. The color changes of dwarf banana in various packaging were showed in Table 1 . The $L$ value tends to decreased along with increase the level of maturity. In the vacuum packaging, the $L$ and $a^{*}$ value were decrease from $69.03 \pm 12.13$ and $10.90 \pm 1.64$ on the day 0 to $75.83 \pm 8.61$ and -

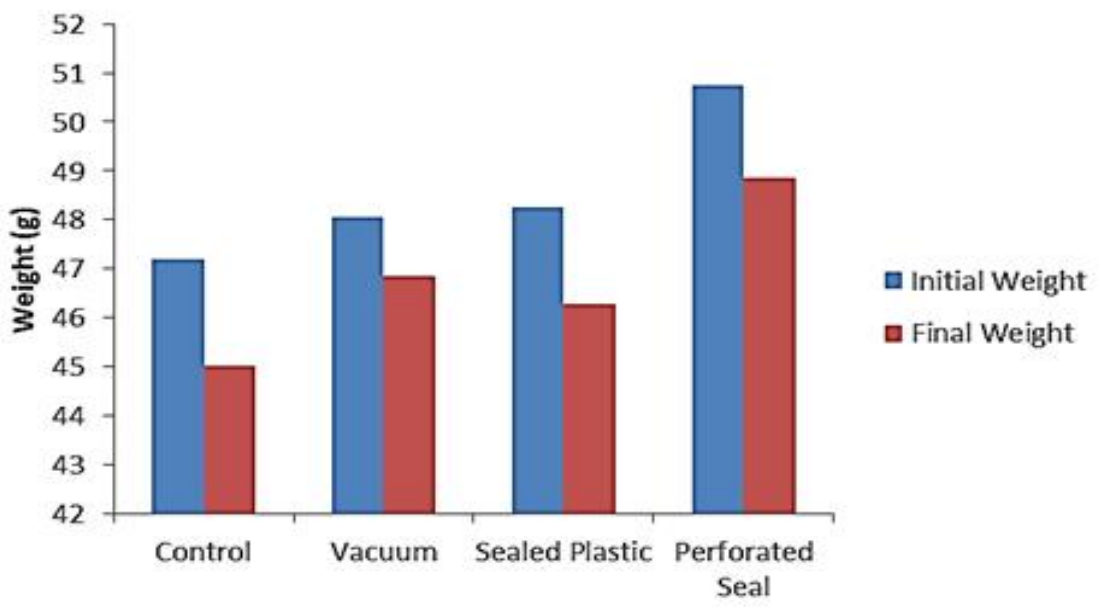

Figure 2. The Weight Changes of Dwarf Banana 


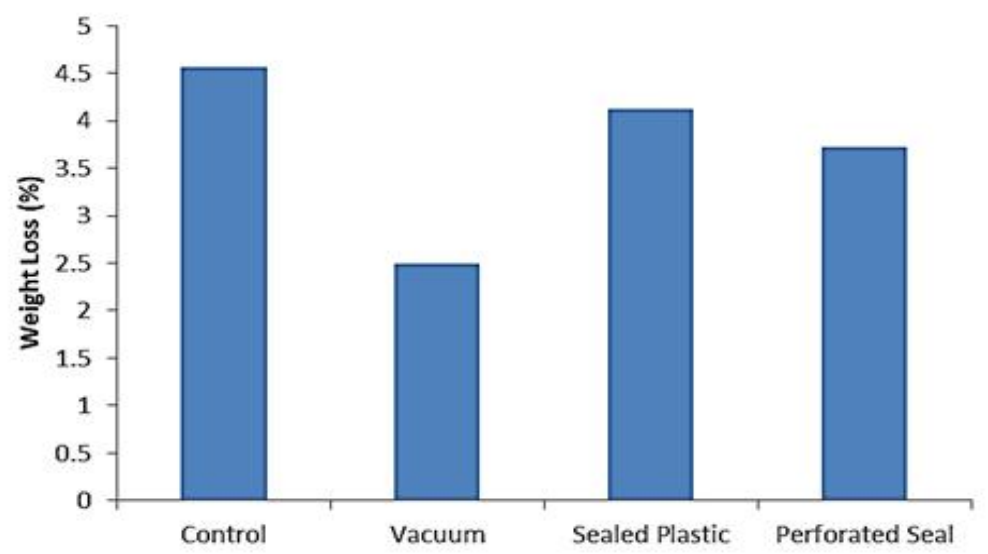

Figure 3. Weight Loss of Dwarf Banana During Packaging Storage

Tabel 1. Color Changes of Dwarf Banana During Packaging Storage

\begin{tabular}{cccccccccc}
\hline \multirow{2}{*}{ Treatment } & \multicolumn{3}{c}{ Day 0 } & \multicolumn{3}{c}{ Day 3 } & \multicolumn{3}{c}{ Day 6 } \\
\cline { 2 - 10 } & $\mathbf{L}$ & $\mathbf{a}^{*}$ & $\mathbf{b}$ & $\mathbf{L}$ & $\mathbf{a}^{*}$ & $\mathbf{b}^{*}$ & $\mathbf{L}$ & $\mathbf{a}^{*}$ & $\mathbf{b}^{*}$ \\
\hline Control & 74.77 & -11.70 & 30.93 & 62.57 & 9.33 & 37.80 & 72.33 & 5.63 & 28.30 \\
Std Deviation & \pm 3.55 & \pm 3.74 & \pm 5.71 & \pm 22.18 & \pm 9.94 & \pm 2.21 & \pm 5.42 & \pm 2.30 & \pm 4.59 \\
\hline Vacuum & 69.03 & -10.90 & 29.33 & 79.07 & -8.73 & 27.87 & 75.83 & -12.10 & 31.83 \\
Std Deviation & \pm 12.13 & \pm 1.64 & \pm 4.35 & \pm 16.74 & \pm 3.88 & \pm 12.57 & \pm 8.61 & \pm 1.65 & \pm 8.82 \\
\hline Sealed Plastic & 64.00 & -15.83 & 26.10 & 74.73 & -3.77 & 35.17 & 73.07 & 2.53 & 26.23 \\
Std Deviation & \pm 4.27 & \pm 1.62 & \pm 10.48 & \pm 2.97 & \pm 2.14 & \pm 10.58 & \pm 6.64 & \pm 1.26 & \pm 2.62 \\
\hline Perforated & 65.27 & -16.90 & 26.20 & 64.93 & -0.57 & 35.10 & 73.47 & 2.07 & 33.40 \\
$\quad$ Seal & & & & & & & & \\
Std Deviation & \pm 1.79 & \pm 2.40 & \pm 3.82 & \pm 18.92 & \pm 5.62 & \pm 6.15 & \pm 7.30 & \pm 2.62 & \pm 11.10 \\
\hline
\end{tabular}

$12.10 \pm 1.65$ on day 6 . Meanwhile, the $b^{*}$ value was increased from $29.33 \pm 4.35$ to $31.83 \pm 8.82$. The transformation of $L, a^{*}$, and $b^{*}$ to Hue showed that the vacuum packaging was able to maintain the green color, while the dwarf banana in other treatments becomes brown (Fig. 4). In the common cases, the banana peel color will start changed from green to yellow in the increase of storage time. Ultimately, the peel color of the banana is going to browning through the metabolism process, followed by the maturity level end. The color change is probably caused by chlorophyll and other pigment degradation, associated with $\mathrm{pH}$ changes, oxidative process development, and action of certain enzymes in the chloroplast (CastroBenítez et al, 2005). Another possibility of peel color changes could come from a lower percentage of relative humidity in the storage room, caused by the modification of the environment around packaging (Hailu et al,, 2014). The maturity level of bananas, indicated by color, will affect consumer preferences, particularly in high-income consumers (Basan, 2017). Therefore, in this study, the vacuum packaging was the best packaging to keep the green color of dwarf banana peel.

A previous study on the impact of packaging materials on the banana peel color changes showed that polyethylene (PE) bag, teff straw, and banana leaf maintained the green color within 16 days, compared to other materials, such as carton box (Tsegaye, 2020). Other results from Hailu et al., (2014) on the impact of different materials, and found that plastic films, such as LDPE and HDPE able to developed excellent types of color of bananas peel during packaging storage, compare to banana leaf and teff straw as materials for packaging. In this study, PE plastic was used to package the dwarf banana. The combination of different types of materials with vacuum packaging will interested results to maintain the peel color of a dwarf banana.

\subsection{Total Soluble Solids Content}

The total soluble solids (TSS) content of each treatment was measured using a refractometer. The TSS of dwarf banana on the day 6 was 


\section{Day 0 Day 3 Day 6 \\ Control
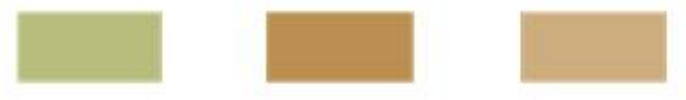 \\ Vacuum
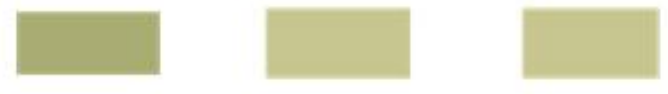 \\ Sealed plastic
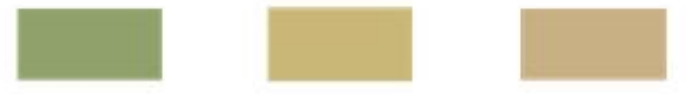 \\ Perforated seal
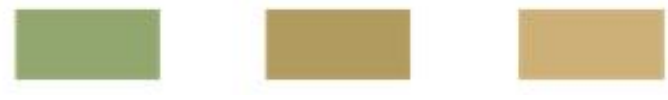

Figure 4. Color Appearances of Dwarf Banana During Packaging (colorizer.org)

One-way ANOVA: TSS versus Treatment
$\begin{array}{lrrrrr}\text { Source } & \text { DF } & \text { SS } & \text { MS } & \text { F } & \text { P } \\ \text { Treatment } & 3 & 72.2867 & 24.0956 & 275.38 & 0.000 \\ \text { Error } & 8 & 0.7000 & 0.0875 & & \\ \text { Total } & 11 & 72.9867 & & & \\ \text { S }=0.2958 & \text { R-Sq }=99.04 \% & \text { R-Sq (adj) }=98.68 \%\end{array}$

Figure 5. Analysis of Variance TSS Content of Dwarf Banana in The Packaging Storage

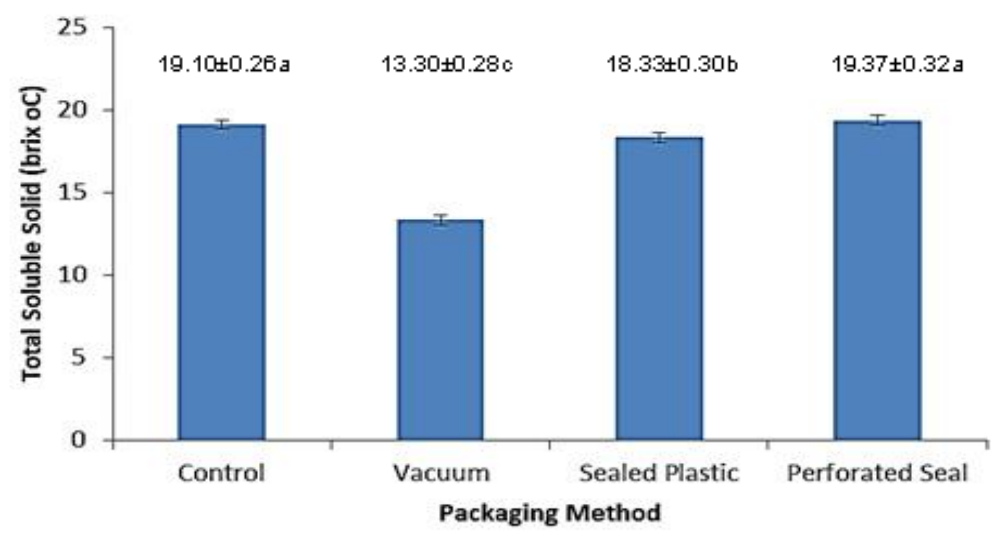

Figure 6. Total Soluble Solids Content of Dwarf Banana in The Packaging Storage

showed in Figure 6. The total soluble solids increased from the initial $8.5 \pm 0.5$ brix to $13.33 \pm 0.28-19.37 \pm 0.32^{\circ} \mathrm{brix}$. The highest TSS was found in the perforated seal packaging on the day $6\left(19.37 \pm 0.32{ }^{\circ}\right.$ brix $)$. Meanwhile, the lowest TSS was found in the vacuum packaging within 6 days of storage. The results of analysis of variance showed that the $P$ value was lower than 0.05 , indicated that the treatment significantly affected the TSS changes of dwarf banana at $\mathrm{p}<0.05$ level according to statistical analysis (Fig 5). The TSS was related to banana maturity stages. Opara et al, (2013) explained that the TSS content of banana at ripe stages is range from $18-23^{\circ} \mathrm{brix}$.

In certain condition, the increasing of TSS content was considered as the fruit ripening, depends on the variety of cultivars. In this study, the lowest TSS was found in the vacuum packaging, indicated it could maintain the maturity of dwarf banana. Identification of other 
physicochemical parameters that related to the shelf life of dwarf banana will give more information about characteristics of vacuum packaging on dwarf banana storage. These results suggest that vacuum packaging is the potential as packaging methods to prolong dwarf banana shelf life.

\section{CONCLUSIONS}

The several physicochemical properties changes of dwarf banana were observed in this study. The lowest of dwarf banana weight loss was found in the vacuum packaging storages. Furthermore, the vacuum packaging was also maintained the green color of dwarf banana, indicated its ability to keep the maturity. Also, the lowest amount of TSS was found in the vacuum packaging. These results suggest that vacuum packaging could be considered as potential packaging methods. However, investigation on other physicochemical would help give more information on it.

\section{REFERENCES}

Baldwin, E.A. 1994. Edible Coatings for Fresh Fruits and Vegetables: Past, Present, and Future. Edible Coatings and Films to Improve Food Quality, 1, p.25.

Basan, R.J.P. 2017. Consumer Preference of Table Banana Quality by Income Groups in The Philippines: Hedonic Price Analysis. Asian Journal of Agriculture and Development, 13(1362-2017-770): 21-34.

BPS. 2019. Produksi Buah-buahan Menurut Provinsi. Badan Pusat Statistik Republik Indonesia. Jakarta.

Castro-Benítez, M., L.P. Restrepo-Sánchez, and C.E. NarváezCuenca. 2005. Actividad de Clorofilasa Durante la Maduración del Banano Bocadillo (Musa acuminata) (Simons). Actual. Biol. 27(83): 151-158.

Dahli, A., Haryanto, A. and Suhandy, D., 2016. Studi Penggunaan KMno4 untuk
Memperpanjang Umur Simpan Pisang Muli. Jurnal Teknik Pertanian Lampung, 5(2):67-72.

Gorris, L.G.M. and Peppelenbos, H.W. 1992. Modified Atmosphere and Vacuum Packaging to Extend The Shelf Life of Respiring Food Products. HortTechnology, 2(3): 303-309.

Hailu, M., Workneh, T.S. and Belew, D. 2014. Effect of Packaging Materials on Shelf Life and Quality of Banana Cultivars (Musa spp.). Journal of food science and technology, 51(11): 2947-2963.

Jideani, A.I. 2019. Introductory chapter: Banana nutrition-function and processing kinetics. In Banana Nutrition-Function and Processing Kinetics. IntechOpen.

Marpaung, D.S.S., Fil'aini, R., Fahrani, A.C., Cahyani, D. and Sinaga, A.O.Y. 2019. Physical Changes of Andaliman (zanthoxylum acanthopodium dc.) in Packaging During Low-temperature Storage. Agrointek, 13(2): 177-182.

Marpaung, D.S.S., Indriyani, A., Fahadha, R.U., Mardiono, I. and Haryanto, A. 2020. Determination of Aflatoxin Contamination Risk Along Maize Distribution Chain (Case Study: A Maize Enterprise in East Lampung). In IOP Conference Series: Earth and Environmental Science (Vol. 537, No. 1, p. 012039). IOP Publishing.

Opara, U.L., Al-Yahyai, R., Al-Waili, N., Said, F.A., Al-Ani, M., Manickavasagan, A. and AlMahdouri, A. 2013. Postharvest Responses of 'Malindi'cavendish Banana to Various Storage Conditions. International Journal of Fruit Science, 13(4): 373-388.

Ravindranath, R., Periasamy, A.P., Roy, P., Chen, Y.W. and Chang, H.T. 2018. Smart Appbased on-field Colorimetric Quantification of Mercury Via Analyte-induced Enhancement of The Photocatalytic Activity of TiO 2-Au Nanospheres. 
Analytical and bioanalytical chemistry, 410(18): 4555-4564.

Sunisha, K., Claudia, K. L., Mathew, G. 2019. Effect of Vacuum and Shrink Packaging on Shelf Life of Banana (Musa paradisiaca). International Research Journal of Engineering and Technology, 6(11):16811685.

Tambunan, K. and Faradilla, R.F. 2019. Aplikasi Edible Coating dari Karagenan dengan Penambahan Xanthan Gum Terhadap Perubahan Mutu Pisang Muli (musa acuminata) Selama Penyimpanan. Jurnal Sains dan Teknologi Pangan, 5(3): 28982910.

Thompson, J.F., Mitchell, F.G. and Rumsay, T.R. 2008. Commercial Cooling of Fruits, Vegetables, and Flowers (Vol. 21567). UCANR Publications.
Tsegaye, K.Z.B. 2020. Effect of Different Packaging Material on Shelf Life and Quality of Banana (musa spp). International Journal of African and Asian Studies. 61:1-6. DOI: 10.7176/JAAS/6101

Venkatachalam, K., Muthuvel, I., Sundaresan, S., Subramanian, K.S., Janaki, J.G., Sullivan, J.A., Paliyath, G. and Subramanian, J. 2018. Post-harvest Dip of Enhanced Freshness Formulation to Extend The Shelf Life of Banana (Musa acuminata cv. Grand Naine) in India. The Journal of the Faculty of Food and Agriculture, 95(1): 1-13.

Yaman, Ö. and Bayo เnd เ rl เ , L . 2002. Effects of an Edible Coating and Cold Storage on Shelf-life and Quality of Cherries. LWTFood science and Technology, 35(2): 146150. 